\title{
Contribution of Ebullition to Methane and Carbon Dioxide Emission from Water between Plant Rows in a Tropical Rice Paddy Field
}

\author{
Shujiro Komiya, ${ }^{1}$ Kosuke Noborio, ${ }^{2}$ Kentaro Katano, ${ }^{3}$ Tiwa Pakoktom, ${ }^{4}$ \\ Meechai Siangliw, ${ }^{5}$ and Theerayut Toojinda ${ }^{5}$ \\ ${ }^{1}$ Graduate School of Agriculture, Meiji University, Kawasaki, Kanagawa 214-8571, Japan \\ ${ }^{2}$ School of Agriculture, Meiji University, Kawasaki, Kanagawa 214-8571, Japan \\ ${ }^{3}$ Formerly Graduate School of Agriculture, Meiji University, Kawasaki, Kanagawa 214-8571, Japan \\ ${ }^{4}$ Department of Agronomy, Kasetsart University, Kamphaeng Saen, Nakhon Pathom 73140, Thailand \\ ${ }^{5}$ Rice Gene Discovery Unit, National Center for Genetic Engineering and Biotechnology (BIOTEC), \\ National Science and Technology Development Agency, Kasetsart University, Kamphaeng Saen, Nakhon Pathom 73140, Thailand
}

Correspondence should be addressed to Kosuke Noborio; noboriok@meiji.ac.jp

Received 12 October 2015; Revised 9 December 2015; Accepted 9 December 2015

Academic Editor: Weixin Ding

Copyright (C) 2015 Shujiro Komiya et al. This is an open access article distributed under the Creative Commons Attribution License, which permits unrestricted use, distribution, and reproduction in any medium, provided the original work is properly cited.

\begin{abstract}
Although bubble ebullition through water in rice paddy fields dominates direct methane $\left(\mathrm{CH}_{4}\right)$ emissions from paddy soil to the atmosphere in tropical regions, the temporal changes and regulating factors of this ebullition are poorly understood. Bubbles in a submerged paddy soil also contain high concentrations of carbon dioxide $\left(\mathrm{CO}_{2}\right)$, implying that $\mathrm{CO}_{2}$ ebullition may occur in addition to $\mathrm{CH}_{4}$ ebullition. We investigated the dynamics of $\mathrm{CH}_{4}$ and $\mathrm{CO}_{2}$ ebullition in tropical rice paddy fields using an automated closed chamber installed between rice plants. Abrupt increases in $\mathrm{CH}_{4}$ concentrations occurred by bubble ebullition. The $\mathrm{CO}_{2}$ concentration in the chamber air suddenly increased at the same time, which indicated that $\mathrm{CO}_{2}$ ebullition was also occurring. The $\mathrm{CH}_{4}$ and $\mathrm{CO}_{2}$ emissions by bubble ebullition were correlated with falling atmospheric pressure and increasing soil surface temperature. The relative contribution of $\mathrm{CH}_{4}$ and $\mathrm{CO}_{2}$ ebullitions to the daily total emissions was $95-97 \%$ and $13-35 \%$, respectively.
\end{abstract}

\section{Introduction}

Understanding the dynamics of methane $\left(\mathrm{CH}_{4}\right)$ and carbon dioxide $\left(\mathrm{CO}_{2}\right)$ fluxes in rice paddy fields is crucial for improving the accuracy of estimating $\mathrm{CH}_{4}$ and $\mathrm{CO}_{2}$ emissions from global rice paddy fields. In particular, flooded rice paddies are considered to be a major source of anthropogenic $\mathrm{CH}_{4}$. Methane emissions from rice paddies in tropical Asian countries account for $90 \%$ of global annual $\mathrm{CH}_{4}$ emissions from rice paddies $[1,2]$.

Methane produced in an anaerobic-flooded paddy soil is mainly transported to the atmosphere through the aerenchyma of rice plants [3-5]. Such emissions through the aerenchyma are estimated to account for $48-85 \%$ of net $\mathrm{CH}_{4}$ emissions throughout the rice-cropping season [5]. In addition, $\mathrm{CO}_{2}$ exchange in paddy fields mainly results from photosynthesis and respiration of rice plants, as well as soil microbial respiration.

Also, some of the $\mathrm{CH}_{4}$ and $\mathrm{CO}_{2}$ produced in rice field soil is directly emitted to the atmosphere through paddy water. In one study, when rice straw was applied to a paddy field, $\mathrm{CH}_{4}$ emissions via bubble ebullition from the soil accounted for $35-62 \%$ of total $\mathrm{CH}_{4}$ emissions [6]. However, research on the direct $\mathrm{CH}_{4}$ and $\mathrm{CO}_{2}$ exchanges between paddy soil and the atmosphere, via paddy water, is limited and so further studies are required on these emissions, as has been noted by other researchers $[7,8]$.

Methane in paddy soil is transported to the atmosphere through paddy water by two pathways: (1) diffusion between soil and atmosphere and (2) bubble ebullition [9]. Methane 
emission by bubble ebullition is considered to be greater than that by diffusion from paddy water [6]. The bubbles usually contain a high concentration of $\mathrm{CH}_{4}$ ranging between 1 and $82 \%(\mathrm{v} / \mathrm{v})[10,11]$ and comprise most of the total $\mathrm{CH}_{4}$ pool in flooded paddy soil [12]. Bubble production and ebullition are enhanced by applied organic materials during the initial plant growth period $[6,13,14]$ and by organic substances originating from rice roots during later growth stages $[6,12$, 14]. Although the variation of $\mathrm{CH}_{4}$ bubble ebullition during the cultivation period has been studied previously, the factors controlling the diurnal changes in $\mathrm{CH}_{4}$ ebullition remain unclear [15].

Methane ebullition from submerged peatlands, which are similar to flooded paddy soil in that they contain many bubbles, is controlled by atmospheric pressure, soil temperature, and water table level [16-19]. Falling atmospheric pressure has been shown to be the most important contributor to $\mathrm{CH}_{4}$ bubbling in peatlands $[18,19]$. A study in rice paddy fields in Thailand also suggested that $\mathrm{CH}_{4}$ ebullitions occurred when atmospheric pressure dropped, but further research is needed to clarify this [20].

In contrast, $\mathrm{CO}_{2}$ exchange through paddy water is the result of photosynthesis of aquatic plants and respiration of both the plants and the soil microorganisms [21]. Emission due to soil respiration is suppressed by paddy water during flood irrigation $[21,22]$, but the $\mathrm{CO}_{2}$ concentration in soil bubbles is between 2.2 and $13.0 \%(\mathrm{v} / \mathrm{v})$ [11, 23], which suggests that bubble ebullition will release both $\mathrm{CH}_{4}$ and $\mathrm{CO}_{2}$ from paddy soil into the atmosphere.

Therefore, in this paper, we examined the dynamics of both $\mathrm{CH}_{4}$ and $\mathrm{CO}_{2}$ ebullition in tropical rice paddy fields in Thailand using an automatically closing chamber method.

\section{Materials and Methods}

Gas field measurements were conducted on September 20th and 21st, 2014, in a rice field of Kasetsart University, Kamphaeng Saen campus $\left(14^{\circ} 00^{\prime} 33^{\prime \prime} \mathrm{N}, 99^{\circ} 59^{\prime} 03^{\prime \prime} \mathrm{E}\right)$ located in Nakhon Pathom Province, Thailand. The soil had a clay texture $(65.7 \%$ clay, $23.30 \%$ silt, and $11.0 \%$ sand) with a dry bulk density of $1.69 \mathrm{~g} \mathrm{~m}^{-3}$. The soil was sampled on September 17 and had a $\mathrm{pH}$ of 6.0 (1:1 for soil : water), $4.32 \%$ organic matter, $1.81 \%$ total carbon, and $1.85 \%$ total nitrogen. Seedlings of the rice variety "Homcholasit" were transplanted on June 30 at $18 \times 30 \mathrm{~cm}$ spacing with $4-5$ seedlings per hill, after the soil had been plowed on June 17 and 26 when weeds and rice plants that had grown during the fallow period were plowed into the soil. The rice plants headed on September 22 and were harvested on October 28. The paddy field was continuously flooded from June 17 until harvest, with flooding water depth maintained at $2-20 \mathrm{~cm}$. During the gas measurement period, the water depth slowly decreased from 5.5 to $4 \mathrm{~cm}$ because there was no precipitation or irrigation.

The $\mathrm{CH}_{4}$ and $\mathrm{CO}_{2}$ fluxes were measured using the automatic closed chamber method. A customized-bottomless polycarbonate chamber $(50 \times 20 \mathrm{~cm}$ at the base and $40 \mathrm{~cm}$ height, Green Blue Corp., Tokyo, Japan) was placed between the rows of rice plants on August 8; the base part was inserted $4.5 \mathrm{~cm}$ deep into the paddy soil (Figure 1 ). The lid of the chamber was automatically closed for 10 min every $1 \mathrm{~h}$ by a pneumatic piston, with the lid kept open for the rest of the time. A small electric fan was installed on the upper sidewall inside the chamber and was kept running throughout the experiment to uniformly mix the air within the chamber. The chamber headspace air was circulated at $500 \mathrm{~mL} \mathrm{~min}^{-1}$ (using a diaphragm pump; TD-4X2N, Brailsford Co., Rye, NY, USA) between the chamber and a $250 \mathrm{~mL}$ buffer tank placed in a shed located approximately $4 \mathrm{~m}$ away from the chamber to minimize the high frequency noise. A loop line was installed between the buffer tank and a wavelengthscanned cavity ring-down spectroscopy $\mathrm{CH}_{4} / \mathrm{CO}_{2}$ analyzer (G2201-i, Picarro Inc., Santa Clara, CA, USA). Air in the buffer tank was withdrawn to the analyzer at a flow rate of $\sim 25 \mathrm{~mL} \mathrm{~min}^{-1}$ using another diaphragm pump (UN84.4 ANDC-B, KNF Neuberger Inc., NJ, USA) and then returned to the loop line. Concentrations of $\mathrm{CH}_{4}$ and $\mathrm{CO}_{2}$ were analyzed at approximately $3.6 \mathrm{~s}$ intervals by the gas analyzer. The sampled air was dried before entering the gas analyzer using a reflux method with a membrane dryer (SWG-A0106, Asahi Glass Engineering Co., Chiba, Japan) so that the water vapor concentration in the air was kept $<0.1 \%$. Based on the internal volumes of the buffer tank and connecting tube and the flow rate the air inside the chamber was calculated to first reach the gas analyzer 2 min after closing the chamber lid. The measurements of $\mathrm{CH}_{4}$ and $\mathrm{CO}_{2}$ concentrations in the chamber air stopped when the chamber lid opened meaning that a measurement cycle of gas flux measurements lasted 8 min every hour.

Temporal changes in $\mathrm{CH}_{4}$ concentration in the chamber during a measurement cycle were categorized into either a sudden increase (Figures 2(a), 2(c), and 2(e)) or a slowconstant increase (Figures 2(c) and 2(e)). Emission by bubble ebullition events was defined as a sudden increase in concentration $(\Delta C / \Delta t)$ of $\geq 0.29 \mathrm{ppm} \mathrm{min}^{-1}$, whereas emission by diffusion was defined as a slow-constant increase $(\Delta C / \Delta t)$ of $<0.29 \mathrm{ppm} \mathrm{min}^{-1}$.

Changes in $\mathrm{CO}_{2}$ concentration in the chamber showed either an episodic increase accompanied by $\mathrm{CH}_{4}$ ebullition events (Figures 2(b) and 2(f)), a steady increase (Figure 2(d)), or a decrease by plant uptake (Figure $2(\mathrm{f})$ ). $\mathrm{CO}_{2}$ emission by bubble ebullition was defined as episodic $\mathrm{CO}_{2}$ concentration increases accompanied by $\mathrm{CH}_{4}$ ebullition, whereas emission by diffusion was defined as a constant $\mathrm{CO}_{2}$ increase. The $\mathrm{CO}_{2}$ uptake by photosynthetically active aquatic plants was defined by a decrease in $\mathrm{CO}_{2}$ concentration (Figure 2(f)) observed during the daytime on both days.

Since $\mathrm{CH}_{4}$ and $\mathrm{CO}_{2}$ concentrations in the chamber often changed episodically with time due to bubble ebullition events (Figures 2(a), 2(b), 2(c), 2(e), and 2(f)), $\mathrm{CH}_{4}$ and $\mathrm{CO}_{2}$ fluxes were calculated for each single flux event and then summed proportionately for the time of each event to give a total flux for each $8 \mathrm{~min}$ measurement period. The start of each flux event was determined as the intersection between tangent lines at the inflection point of the time series of $\mathrm{CH}_{4}$ or $\mathrm{CO}_{2}$ concentrations (Figure 2). The end of each event was the time just before the start of the next flux event or the end of the $8 \mathrm{~min}$ measurement period (Figure 2). The gas flux 


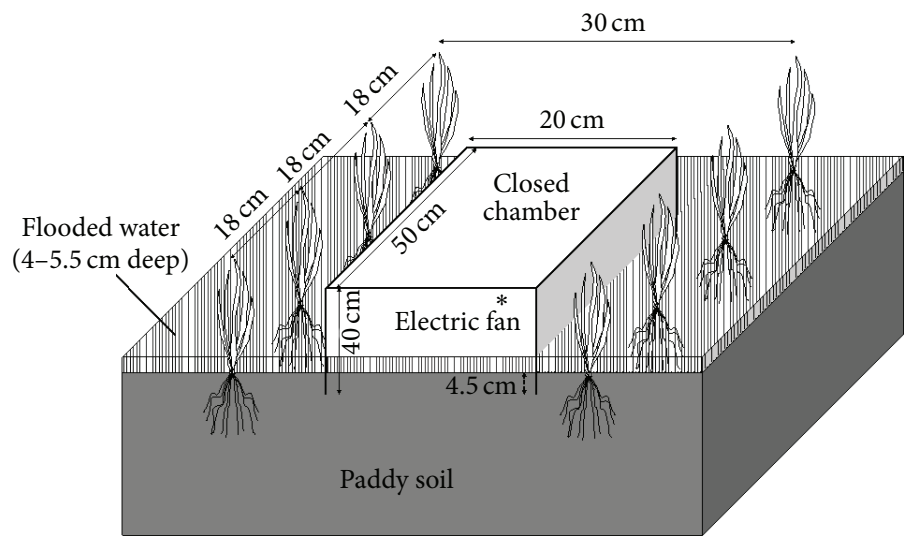

FIGURE 1: Schematic diagram of an automatic closed chamber placed between the rows of rice plants.

$F\left(\mathrm{mg} \mathrm{m}^{-2} \mathrm{~h}^{-1}\right)$ was calculated using temporal changes in gas concentrations as [24]

$$
F=\frac{V}{A}\left[\frac{d C(t)}{d t}\right]_{t=0},
$$

where $V$ is the headspace volume within the chamber $\left(\mathrm{m}^{3}\right)$, $A$ is the water-surface area covered by the chamber $\left(\mathrm{m}^{2}\right)$, $t$ is elapsed time (h), and $C(t)$ is temporal changes in gas concentration $\left(\mathrm{mg} \mathrm{m}^{-3}\right)$ expressed as

$$
C(t)=C_{\max }-\left(C_{\max }-C_{0}\right) \exp (-k t)
$$

where $C_{\max }$ is the maximum gas concentration $\left(\mathrm{mg} \mathrm{m}^{-3}\right)$, $C_{0}$ is the initial gas concentration $\left(\mathrm{mg} \mathrm{m}^{-3}\right)$, and $k$ is a rate constant. The values of $C_{\max }, C_{0}$, and $k$ were iteratively obtained using the data of observed gas concentration versus time. Substituting (2) at $t=0$ into (1) means that the gas flux $F\left(\mathrm{mg} \mathrm{m}^{-2} \mathrm{~h}^{-1}\right)$ can be calculated as [24]

$$
F=\frac{V}{A} k\left(C_{\max }-C_{0}\right) \text {. }
$$

Atmospheric pressure and air temperature were measured with a barometer (MPXAZ6115A and MPXV7007DP, Freescale Inc., TX, USA) and a thermometer (HMP45A, Vaisala Inc., Helsinki, Finland), respectively. Water depth in the rice field was measured with a water level sensor (eTape Continuous Fluid Level Sensor, Milone Technologies Inc., NJ, USA). Soil surface temperature was measured with a type $\mathrm{T}$ thermocouple.

Bubbles in soil were collected directly with a syringe by disturbing the topsoil at 3 p.m. local time on September 20. The $\mathrm{CH}_{4}$ and $\mathrm{CO}_{2}$ concentrations in the bubbles were measured using the $\mathrm{CH}_{4} / \mathrm{CO}_{2}$ gas analyzer after the sampled air was diluted 101 times with high-purity nitrogen gas.

\section{Results and Discussion}

3.1. $\mathrm{CH}_{4}$ Emission. Episodic and rapid increases in $\mathrm{CH}_{4}$ concentration were identified in 21 out of the 46 measurements (Figures 2(a), 2(c), and 2(e)). These sudden increases in
$\mathrm{CH}_{4}$ concentration are likely to be from bubbles released from the soil to the atmosphere because the $\mathrm{CH}_{4}$ concentration in topsoil bubbles was as high as $63.73 \% \mathrm{v} / \mathrm{v}$. In the other 25 measurements, the $\mathrm{CH}_{4}$ concentration in the chamber air increased gradually with time $\left(\Delta \mathrm{CH}_{4} / \Delta t<\right.$ $0.29 \mathrm{ppm} \mathrm{min}^{-1}$ ) during the closure period, indicating that $\mathrm{CH}_{4}$ was released from the water surface to the atmosphere by molecular diffusion. The $\mathrm{CH}_{4}$ fluxes at the water surface fluctuated between 0.7 and $218.7 \mathrm{mg} \mathrm{m}^{-2} \mathrm{~h}^{-1}$ on the observation days, which are similar to previously reported values of -0.6-192.0 $\mathrm{mg} \mathrm{m}^{-2} \mathrm{~h}^{-1}$ [25].

The large $\mathrm{CH}_{4}$ emissions via bubble ebullition mainly occurred between 10:00 a.m. and 5:00 p.m. local time (Figure 3(a)). During this period, atmospheric pressure markedly decreased and reached a minimum value (Figure 3(b)). A night-time $\mathrm{CH}_{4}$ ebullition event also occurred at 2:50 a.m. local time on September 21 (Figures 2(c), 3(a), and 3(b)), once again when air pressure decreased. There was a significant negative linear correlation between atmospheric pressure and $\log _{10}-\mathrm{CH}_{4}$ emission by bubble ebullition (Figure 4; $r=-0.77, p<0.001$ ). These results suggesting that decreases in atmospheric pressure triggered the $\mathrm{CH}_{4}$ ebullitions in the tropical rice paddy field are supported by the findings of Tokida et al. [18, 19] who reported that decreases in atmospheric pressure triggered $\mathrm{CH}_{4}$ ebullitions in peatlands.

In peatlands, air pressure reduction expands bubble volume and thereby enhances bubble buoyancy which causes the bubbles to rise to the water surface [16]. Reduced air pressure also increases the $\mathrm{CH}_{4}$ concentration of gas bubbles by degassing dissolved $\mathrm{CH}_{4}$ in soil solution [16, 26, 27]. These factors probably caused the higher $\mathrm{CH}_{4}$ emissions via ebullition that were found in the current study. Moreover, the higher $\mathrm{CH}_{4}$ ebullition emissions in the daytime, compared with nighttime, are probably due to larger decreases in daytime atmospheric pressure which would increase the volume of the bubbles and the $\mathrm{CH}_{4}$ concentration.

Rising soil temperature also increases the buoyancy and $\mathrm{CH}_{4}$ concentration of bubbles as barometric pressure decreases [17, 27]. In the current study, soil surface temperature increased from around 6:30 a.m. and reached 


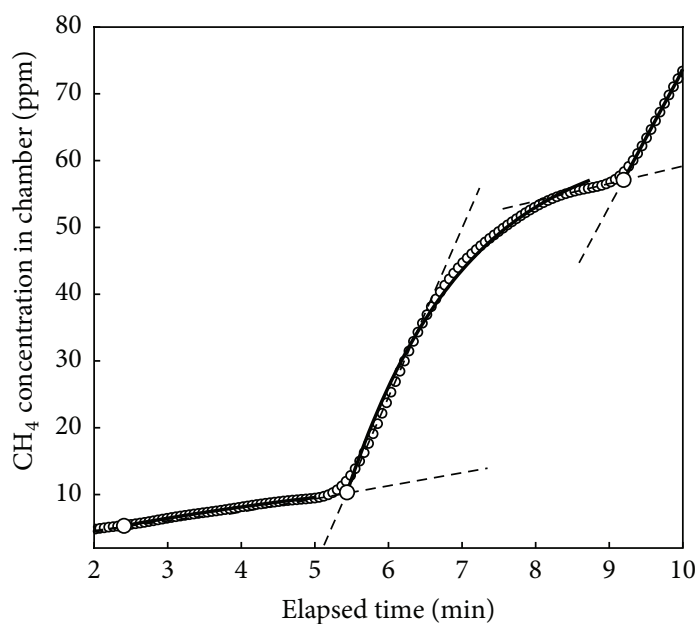

(a) 20/9 2:50 p.m.

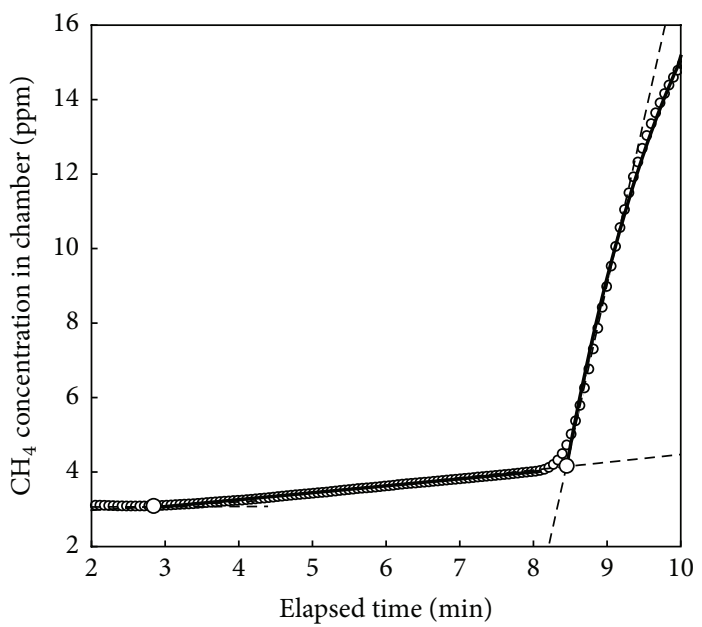

(c) 21/9 2:50 a.m.

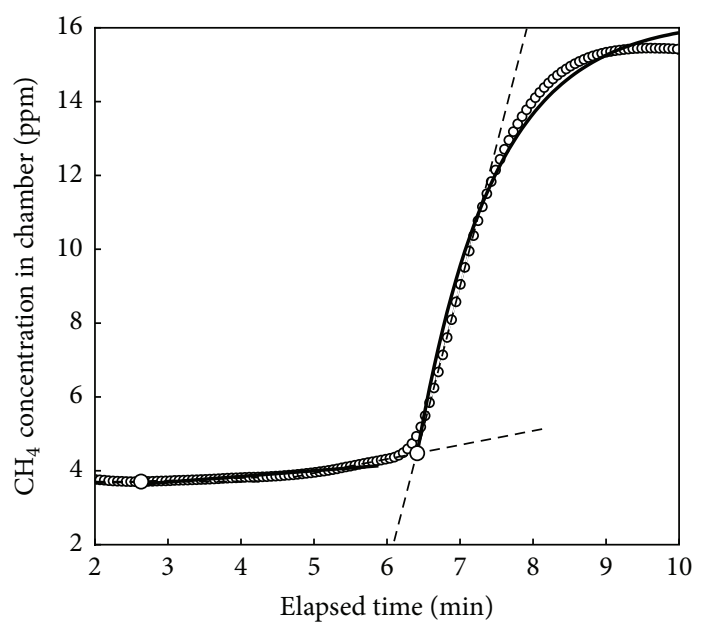

(e) 21/9 4:50 p.m.

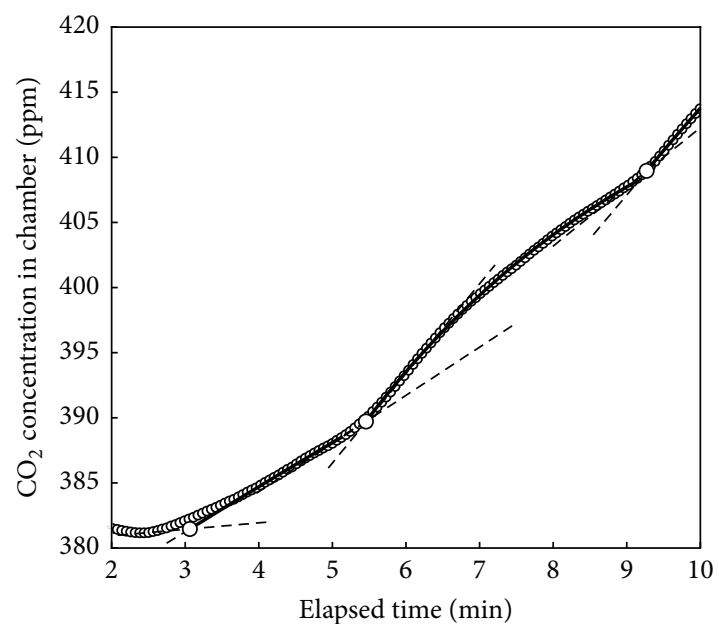

(b) $20 / 9$ 2:50 p.m.

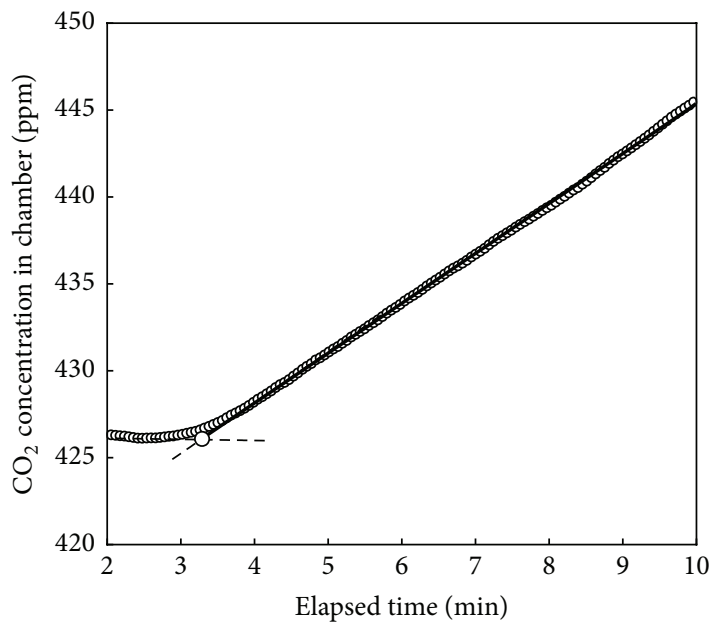

(d) 21/9 2:50 a.m.

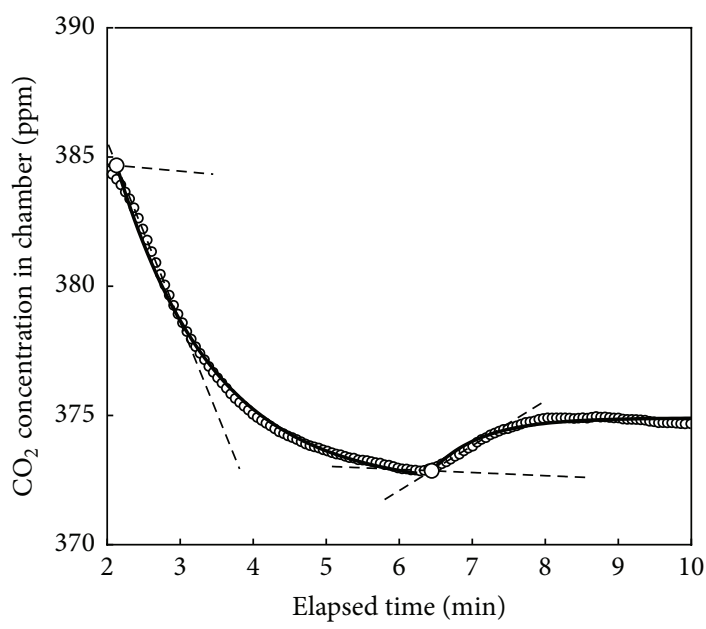

(f) 21/9 4:50 p.m.

FIGURE 2: Examples of the changes in $\mathrm{CH}_{4}, \mathrm{CO}_{2}$ concentrations (7-point running average) in the closed chamber measured at 2:50 p.m. on September 20 ((a), (b)), at 2:50 a.m. on September 21 ((c), (d)), and at 4:50 p.m. on September 21 ((e), (f)). The solid line denotes the best fitting line for each emission/uptake. The white circle with black edge indicates the event starting point. The dashed lines denote the tangent lines at the local maximum or minimum points for $\mathrm{CH}_{4}, \mathrm{CO}_{2}$ emission/uptake rates, before respective increase or decrease events. 
TABLE 1: Cumulative $\mathrm{CH}_{4}$ emissions and relative contribution of bubble ebullition and diffusion processes to total emissions.

\begin{tabular}{lccccc}
\hline Date & $\begin{array}{c}\mathrm{CH}_{4} \text { ebullition } \\
\left(\mathrm{mg} \mathrm{m}^{-2} \mathrm{~d}^{-1}\right)\end{array}$ & $\begin{array}{c}\text { Via } \mathrm{CH}_{4} \text { ebullition } \\
(\%)\end{array}$ & $\begin{array}{c}\mathrm{CH}_{4} \text { diffusion } \\
\left(\mathrm{mg} \mathrm{m}^{-2} \mathrm{~d}^{-1}\right)\end{array}$ & $\begin{array}{c}\mathrm{Via}_{4} \text { diffusion } \\
(\%)\end{array}$ & $\begin{array}{c}\text { Total } \mathrm{CH}_{4} \text { emission } \\
\left(\mathrm{mg} \mathrm{m}^{-2} \mathrm{~d}^{-1}\right)\end{array}$ \\
\hline Sep. 20 & 617.4 & 95.3 & 30.3 & 4.7 & 647.7 \\
Sep. 21 & 546.2 & 96.3 & 20.9 & 3.7 & 567.1 \\
\hline
\end{tabular}

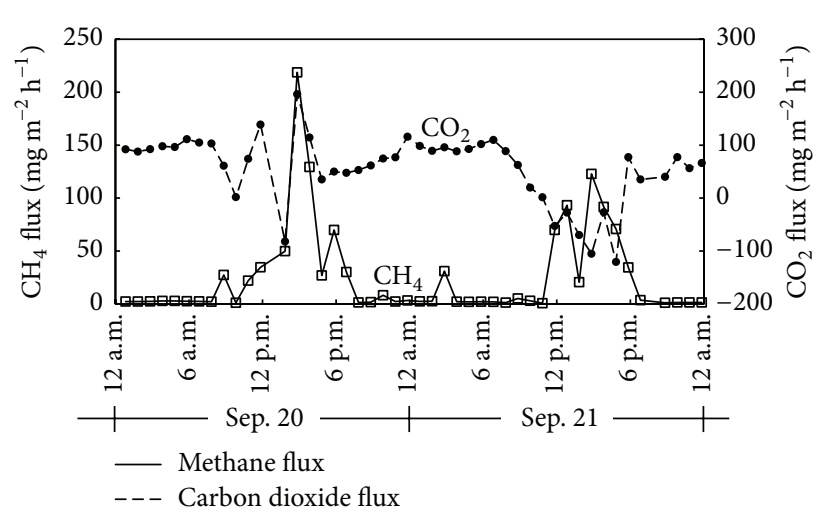

(a)

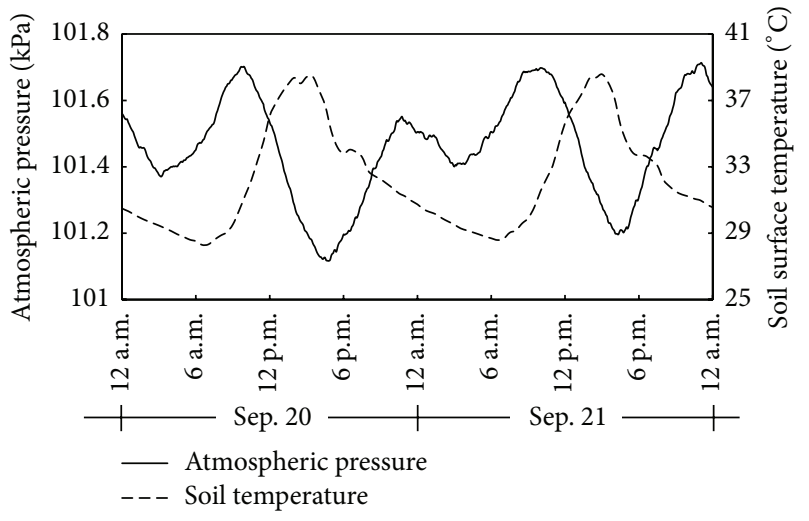

(b)

Figure 3: Temporal changes on September 20 and 21 in $\mathrm{CH}_{4}$ and $\mathrm{CO}_{2}$ fluxes measured with the automatic closed chamber method (a) and atmospheric pressure and soil surface temperature (b).

a maximum value at 3:00-3:30 p.m. on each day (Figure 3(b)). This period approximately corresponded to that when $\mathrm{CH}_{4}$ ebullition events frequently occurred. The positive and significant correlation between soil surface temperature and $\log _{10}-\mathrm{CH}_{4}$ emission via bubble ebullition $(r=0.66 ; p<$ 0.005 ; Figure $4(\mathrm{~b}))$ indicates that the increase in soil surface temperature contributed to $\mathrm{CH}_{4}$ ebullitions in the daytime. Ebullition events occurred at 8:50 a.m. on both days and at 9:50 a.m. on September 21, even though atmospheric pressure did not fall between 6:30 a.m. and 10:00 a.m. on either day. These ebullitions indicate that the rising soil temperature principally triggered the release of bubbles at those times. Rising soil temperature also has a role in enhancing methanogenic activities, leading to increases in $\mathrm{CH}_{4}$ production in soil [28]. Therefore such increased biological activities might have also increased the $\mathrm{CH}_{4}$ concentration in the bubbles.

$\mathrm{CH}_{4}$ emission via bubble ebullition (546-617 $\mathrm{mg} \mathrm{m}^{-2} \mathrm{~d}^{-1}$ ) contributed $95-96 \%$ of total daily $\mathrm{CH}_{4}$ emission (567$647 \mathrm{mg} \mathrm{m}^{-2} \mathrm{~d}^{-1}$ ) through flooded water (Table 1). These $\mathrm{CH}_{4}$ ebullitions mainly occurred in the daytime and were associated with falling atmospheric pressure and increasing soil temperature, as discussed above (Figures 3(a) and 3(b)). In contrast, $\mathrm{CH}_{4}$ emission by diffusion $\left(21-30 \mathrm{mg} \mathrm{m}^{-2} \mathrm{~d}^{-1}\right.$ ) accounted for only 3.7-4.7\% of total daily $\mathrm{CH}_{4}$ emission from flooded water (Table 1). The $\mathrm{CH}_{4}$ emissions by diffusion were mostly observed at nighttime when soil temperature decreased (Figures 3(a) and 3(b)). Therefore, these results clearly show that $\mathrm{CH}_{4}$ emission in rice paddy fields is predominant by daytime ebullition from flooded water with much lower $\mathrm{CH}_{4}$ emissions at nighttime by diffusion.
3.2. $\mathrm{CO}_{2}$ Emission. Episodic increases in $\mathrm{CO}_{2}$ concentration were found in 14 of the 21 measurements when $\mathrm{CH}_{4}$ ebullition events occurred. During these 14 chamber closure periods, the $\mathrm{CO}_{2}$ concentration in the chamber air increased abruptly (Figures 2(b) and 2(f)) at about the same time as $\mathrm{CH}_{4}$ concentration increased (Figures 2(a) and 2(e)). These similar patterns indicate that $\mathrm{CO}_{2}$ was released to the atmosphere in the bubbles along with the $\mathrm{CH}_{4}$. In the other 7 measurements, there was a steady increase in $\mathrm{CO}_{2}$ concentration but no episodic increase, as shown in Figure 2(d), while $\mathrm{CH}_{4}$ concentration abruptly increased (Figure 2(c)). This suggests these bubbles did not contain much $\mathrm{CO}_{2}$.

$\mathrm{CO}_{2}$ uptake via the photosynthetic activities of the aquatic plants was also observed in these measurements. In the other 25 measurements, there was a transfer of $\mathrm{CO}_{2}$ from flooded water to the atmosphere by diffusion, likely due to the gradient in $\mathrm{CO}_{2}$ concentration at the interface between the flooded water and the atmosphere and also due to respiration of the aquatic plants [21]. The values of $\mathrm{CO}_{2}$ fluxes ranged between -120.4 and $196.2 \mathrm{mg} \mathrm{m}^{-2} \mathrm{~h}^{-1}$ which are within the previously reported range of -285.1 to $459.4 \mathrm{mg} \mathrm{m}^{-2} \mathrm{~h}^{-1}$ [29].

On September 20, most of the $\mathrm{CO}_{2}$ fluxes were outgoing emissions due to bubble ebullitions. The highest $\mathrm{CO}_{2}$ emission (196.2 $\mathrm{mg} \mathrm{m}^{-2} \mathrm{~h}^{-1}$ ) occurred at 2:50 p.m. (Figures 2 (d) and $3(\mathrm{a})$ ), coinciding with a high $\mathrm{CO}_{2}$ concentration in the bubbles of up to $11.74 \%$ (v/v). However, at 1:50 p.m., there was a negative (incoming) $\mathrm{CO}_{2}$ flux, even though there was a $\mathrm{CO}_{2}$ ebullition event. This overall negative flux must have been due to the fact that $\mathrm{CO}_{2}$ uptake by photosynthesis of the aquatic plants exceeded emissions by bubble ebullition, as shown in Figure 2(f) for $\mathrm{CO}_{2}$ transfer. 


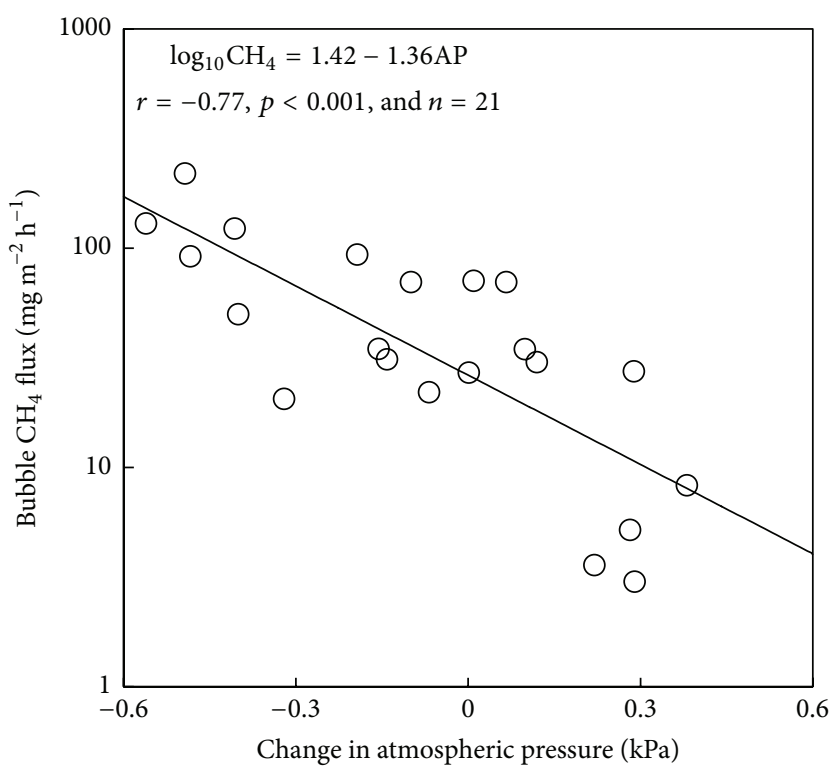

(a)

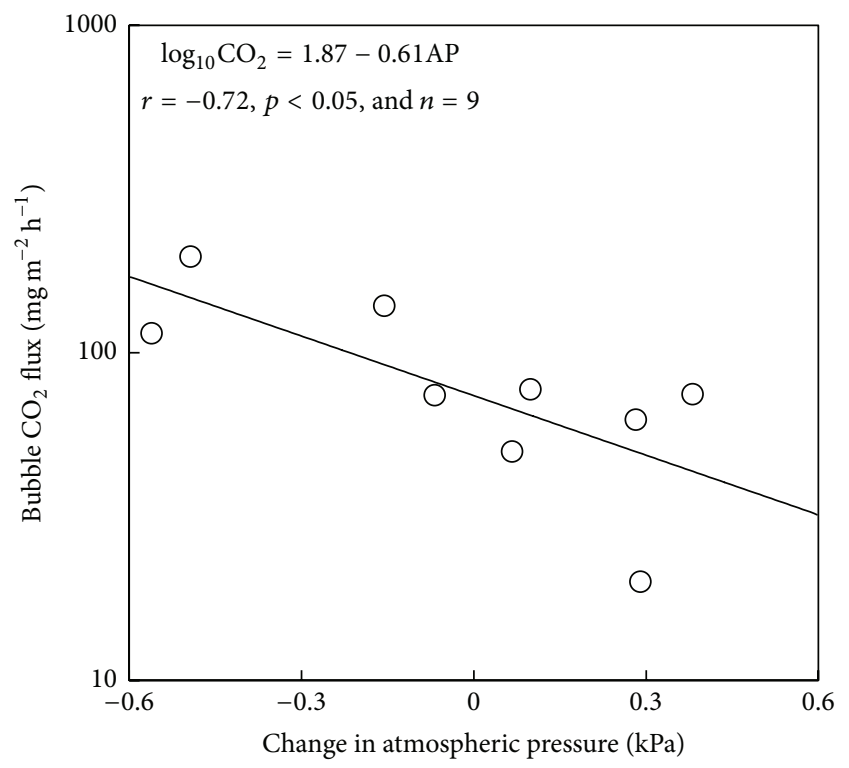

(c)

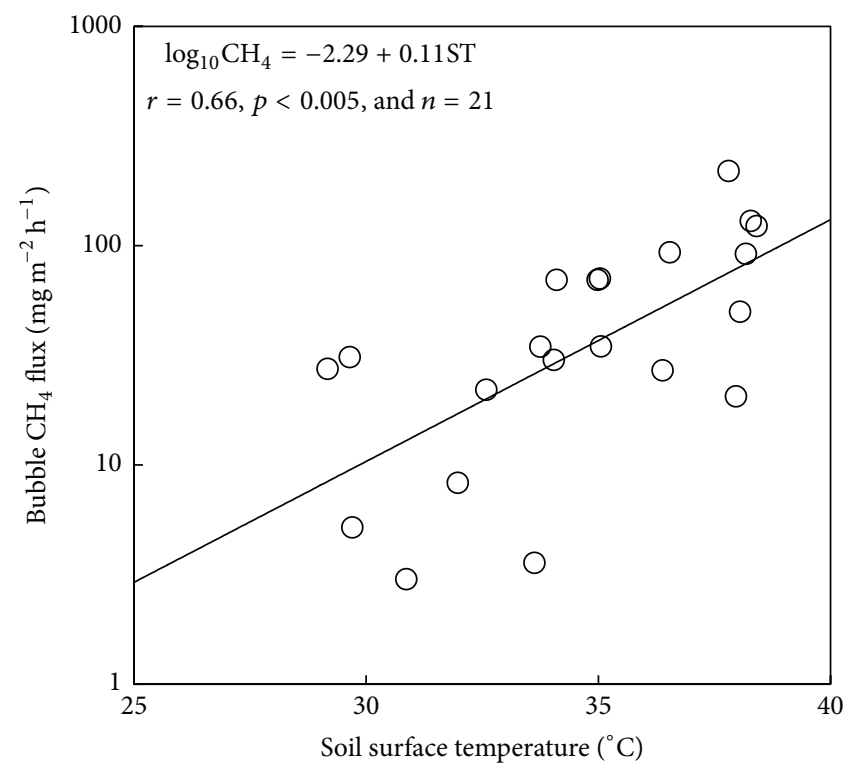

(b)

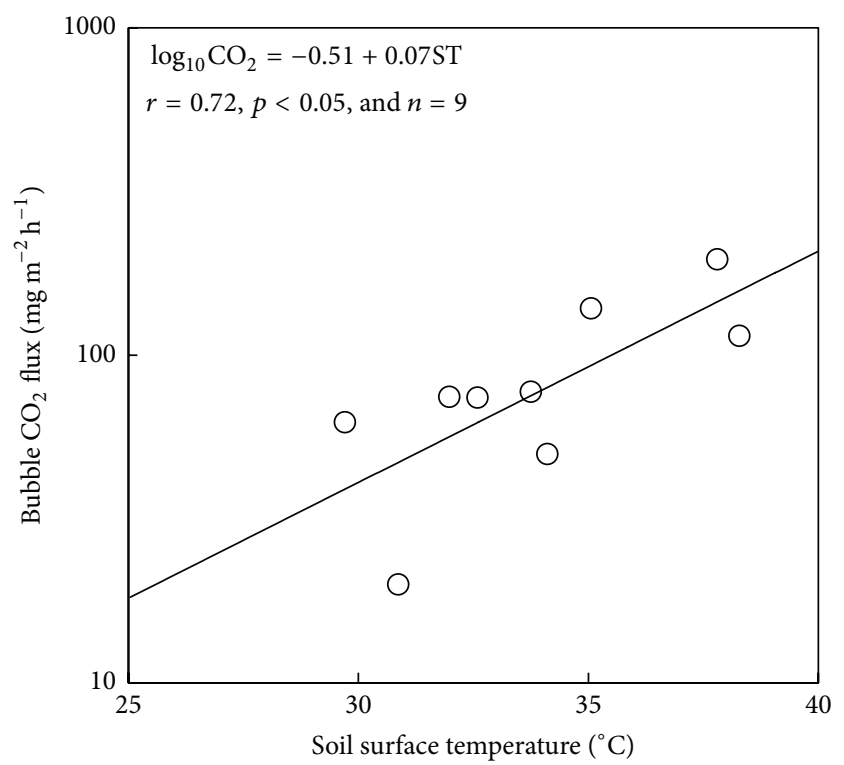

(d)

FIGURE 4: Relationship between $\mathrm{CH}_{4}$ emission by bubble ebullition and change of atmospheric pressure (a) or soil surface temperature (b). Relationship between $\mathrm{CO}_{2}$ emission by bubble ebullition and change of atmospheric pressure (c) or soil surface temperature (d). The change in atmospheric pressure was determined as the difference between the local maximum or minimum value and the value closest to the time when the $\mathrm{CH}_{4}$ or $\mathrm{CO}_{2}$ ebullition occurred.

During the daytime on September 21, the $\mathrm{CO}_{2}$ fluxes mainly showed negative values even though $\mathrm{CO}_{2}$ ebullition events were observed. Therefore, this indicates that $\mathrm{CO}_{2}$ assimilation by the aquatic plants dominated $\mathrm{CO}_{2}$ fluxes on that day.

The $\log _{10}-\mathrm{CO}_{2}$ emissions by bubble ebullitions, omitting measurements with evidence of absorption by plant photosynthesis, were significantly correlated to changes in atmospheric pressure $(r=-0.72 ; p<0.05$; Figure $4(\mathrm{c}))$ and soil surface temperature $(r=0.72 ; p<0.05$; Figure $4(\mathrm{~d}))$. This indicates that these two environmental factors control
$\mathrm{CO}_{2}$ ebullition in addition to $\mathrm{CH}_{4}$ ebullition. As previously discussed, these two triggered expanding bubble volume and degassing of gas dissolved in soil solution $[16,17]$. In addition, the soil surface temperature was between 27 and $40^{\circ} \mathrm{C}$ during the measuring period which was optimal for respiratory soil microbes in the submerged paddy soil [28]. Therefore, all these factors probably enhanced $\mathrm{CO}_{2}$ bubble ebullitions.

$\mathrm{CO}_{2}$ emission by bubble ebullition, accounted for only $13-35 \%$ of total $\mathrm{CO}_{2}$ emissions, compared with $65-87 \%$ from $\mathrm{CO}_{2}$ diffusion (Table 2), indicating that $\mathrm{CO}_{2}$ ebullition did not dominate $\mathrm{CO}_{2}$ emissions from flooded water unlike $\mathrm{CH}_{4}$ 
TABLE 2: Cumulative $\mathrm{CO}_{2}$ emissions and relative contributions of bubble ebullition and diffusion processes to total emissions.

\begin{tabular}{lccccc}
\hline Date & $\begin{array}{c}\mathrm{CO}_{2} \text { ebullition } \\
\left(\mathrm{mg} \mathrm{m}^{-2} \mathrm{~d}^{-1}\right)\end{array}$ & $\begin{array}{c}\text { Via } \mathrm{CO}_{2} \text { ebullition } \\
(\%)\end{array}$ & $\begin{array}{c}\mathrm{CO}_{2} \text { diffusion } \\
\left(\mathrm{mg} \mathrm{m}^{-2} \mathrm{~d}^{-1}\right)\end{array}$ & $\begin{array}{c}\mathrm{Via}_{2} \text { diffusion } \\
(\%)\end{array}$ & $\begin{array}{c}\text { Total } \mathrm{CO}_{2} \text { emission } \\
\left(\mathrm{mg} \mathrm{m}^{-2} \mathrm{~d}^{-1}\right)\end{array}$ \\
\hline Sep. 20 & 648.2 & 35.0 & 1203.8 & 65.0 & 1852.0 \\
Sep. 21 & 159.7 & 13.3 & 1040.4 & 86.7 & 1200.1 \\
\hline
\end{tabular}

ebullition. This is probably due to the fact that $\mathrm{CO}_{2}$ uptake by aquatic plants would have exceeded $\mathrm{CO}_{2}$ emission by bubble ebullition. Moreover, the very low concentration of $\mathrm{CO}_{2}$ in the bubbles also contributed to lower $\mathrm{CO}_{2}$ emission by bubble ebullition. The $\mathrm{CO}_{2}$ emissions by diffusion mostly occurred at nighttime just like for $\mathrm{CH}_{4}$. The nighttime $\mathrm{CO}_{2}$ emissions by diffusion were mostly attributed to the gradient in $\mathrm{CO}_{2}$ concentrations between the atmosphere and the flooded water and also to $\mathrm{CO}_{2}$ respiration by small aquatic plants [21].

\section{Conclusions}

Our study found that daytime $\mathrm{CH}_{4}$ ebullition events in tropical rice paddy fields occurred due to falling atmospheric pressure and increasing soil surface temperature. At nighttime, the drop in atmospheric pressure predominately triggered the $\mathrm{CH}_{4}$ ebullition because soil temperature was low compared with that in the daytime. The fact that $\mathrm{CH}_{4}$ and $\mathrm{CO}_{2}$ concentrations in the chamber air increased abruptly when bubbles were released suggests that bubble ebullition events caused not only $\mathrm{CH}_{4}$ emission but also $\mathrm{CO}_{2}$ emission. The $\mathrm{CO}_{2}$ ebullition events were also controlled by decreases in air pressure and increases in soil temperature. Therefore, diurnal changes in atmospheric pressure and soil temperature play major roles in regulating $\mathrm{CH}_{4}$ and $\mathrm{CO}_{2}$ ebullitions in tropical rice paddy fields.

We also found that $\mathrm{CH}_{4}$ emission was predominant due to daytime ebullition, whereas only a small proportion of $\mathrm{CO}_{2}$ emissions was due to daytime ebullition. The low $\mathrm{CO}_{2}$ ebullition throughout the day was due to $\mathrm{CO}_{2}$ photosynthesis and respiration by aquatic plants, meaning that $\mathrm{CO}_{2}$ emission was mainly by diffusion between flooded water and the atmosphere.

\section{Conflict of Interests}

The authors declare that there is no conflict of interests regarding the publication of this paper.

\section{Acknowledgments}

This research was partly supported by Grant-in-Aid for Scientific Research (A) (25252044, PI: K. Noborio), a JSPS Fellowship (DC1, 12J10924, for S. Komiya) by the Japan Society for the Promotion of Science, and a Program for Establishing Strategic Research Foundations in Private Universities (S0901028, PI: K. Noborio) by MEXT of Japan. The authors are grateful to Dr. Jonaliza Siangliw (BIOTEC) and Ms. Rungthip Kohkhoo for their support at our experimental field, to Dr. Fumiyoshi Kondo (National Institute for Environmental Studies), Dr. Takeshi Tokida, and Dr. Seiichiro Yonemura (National Institute for Agro-Environmental Sciences) for their valuable comments, to Dr. Iain McTaggart (Meiji University) for reviewing a draft, to Dr. Masaru Mizoguchi (University of Tokyo) for making the water level sensor, to Mr. Ryoji Taniyama (Takumi Technical Laboratory Inc., Japan) for assisting with data analysis, to Mr. Ryo Higuchi for making the sensors, and to Mr. Shinsuke Aoki, Mr. Naoto Sato, and Mr. Ryuta Honda for analyzing soil samples. Experimental information and data are available on request to K. Noborio.

\section{References}

[1] X. Yan, H. Akiyama, K. Yagi, and H. Akimoto, "Global estimations of the inventory and mitigation potential of methane emissions from rice cultivation conducted using the 2006 Intergovernmental Panel on Climate Change guidelines," Global Biogeochemical Cycles, vol. 23, no. 2, Article ID GB2002, 2009.

[2] IPCC, Climate Change 2013: The Physical Science Basis, Contribution of Working Group I to the Fifth Assessment Report of the Intergovernmental Panel on Climate Change, Cambridge University Press, New York, NY, USA, 2013.

[3] I. Nouchi, S. Mariko, and K. Aoki, "Mechanism of methane transport from the rhizosphere to the atmosphere through rice plants," Plant Physiology, vol. 94, no. 1, pp. 59-66, 1990.

[4] K. Butterbach-Bahl, H. Papen, and H. Rennenberg, "Impact of gas transport through rice cultivars on methane emission from rice paddy fields," Plant, Cell and Environment, vol. 20, no. 9, pp. 1175-1183, 1997.

[5] R. Wassmann and M. S. Aulakh, "The role of rice plants in regulating mechanisms of methane missions," Biology and Fertility of Soils, vol. 31, no. 1, pp. 20-29, 2000.

[6] R. Wassmann, H. U. Neue, M. C. Alberto et al., "Fluxes and pools of methane in wetland rice soils with varying organic inputs," Environmental Monitoring and Assessment, vol. 42, no. 1-2, pp. 163-173, 1996.

[7] Y. Usui, M. I. M. Mowjood, and T. Kasubuchi, "Absorption and emission of $\mathrm{CO}_{2}$ by ponded water of a paddy field," Soil Science and Plant Nutrition, vol. 49, no. 6, pp. 853-857, 2003.

[8] S. M. Green, "Ebullition of methane from rice paddies: the importance of furthering understanding," Plant and Soil, vol. 370, no. 1-2, pp. 31-34, 2013.

[9] H. Schütz, W. Seiler, and R. Conrad, "Processes involved in formation and emission of methane in rice paddies," Biogeochemistry, vol. 7, no. 1, pp. 33-53, 1989.

[10] M. Uzaki, H. Mizutani, and E. Wada, "Carbon isotope composition of $\mathrm{CH}_{4}$ from rice paddies in Japan," Biogeochemistry, vol. 13, no. 2, pp. 159-175, 1991.

[11] F. Rothfuss and R. Conrad, "Effect of gas bubbles on the diffusive flux of methane in anoxic paddy soil," Limnology and Oceanography, vol. 43, no. 7, pp. 1511-1518, 1998. 
[12] T. Tokida, W. Cheng, M. Adachi et al., "The contribution of entrapped gas bubbles to the soil methane pool and their role in methane emission from rice paddy soil in free-air $\left[\mathrm{CO}_{2}\right]$ enrichment and soil warming experiments," Plant and Soil, vol. 364, no. 1-2, pp. 131-143, 2013.

[13] H. A. C. D. van der Gon and H. U. Neue, "Influence of organic matter incorporation on the methane emission from a wetland rice field," Global Biogeochemical Cycles, vol. 9, no. 1, pp. 11-22, 1995.

[14] A. Watanabe and M. Kimura, "Methane production and its fate in paddy fields. VIII. Seasonal variations in the amount of methane retained in soil," Soil Science and Plant Nutrition, vol. 41, no. 2, pp. 225-233, 1995.

[15] H. U. Neue, "Fluxes of methane from rice fields and potential for mitigation," Soil Use and Management, vol. 13, supplement 4, pp. 258-267, 1997.

[16] E. J. Fechner-Levy and H. F. Hemond, "Trapped methane volume and potential effects on methane ebullition in a northern peatland," Limnology and Oceanography, vol. 41, no. 7, pp. 13751383, 1996.

[17] E. Kellner, A. J. Baird, M. Oosterwoud, K. Harrison, and J. M. Waddington, "Effect temperature and atmospheric pressure on methane $\left(\mathrm{CH}_{4}\right)$ ebullition from near-surface peats," Geophysical Research Letters, vol. 33, no. 18, Article ID L18405, pp. 1-5, 2006.

[18] T. Tokida, T. Miyazaki, and M. Mizoguchi, "Ebullition of methane from peat with falling atmospheric pressure," Geophysical Research Letters, vol. 32, no. 13, pp. 1-4, 2005.

[19] T. Tokida, T. Miyazaki, M. Mizoguchi et al., "Falling atmospheric pressure as a trigger for methane ebullition from peatland," Global Biogeochemical Cycles, vol. 21, no. 2, pp. 1-8, 2007.

[20] S. Komiya, K. Noborio, Y. Shoji, T. Yazaki, and T. Toojinda, "Measuring $\mathrm{CH} 4$ flux in a rice paddy field in Thailand using relaxed eddy accumulation (REA) method," Journal of the Japanese Society of Soil Physics, vol. 128, pp. 23-31, 2014 (Japanese).

[21] H. Koizumi, T. Kibe, S. Mariko et al., "Effect of free-air $\mathrm{CO}_{2}$ enrichment (FACE) on $\mathrm{CO}_{2}$ exchange at the flood-water surface in a rice paddy field," New Phytologist, vol. 150, no. 2, pp. 231-239, 2001.

[22] S. Nishimura, S. Yonemura, K. Minamikawa, and K. Yagi, "Seasonal and diurnal variations in net carbon dioxide flux throughout the year from soil in paddy field," Journal of Geophysical Research G: Biogeosciences, vol. 120, no. 1, pp. 6376, 2015.

[23] W. Cheng, K. Yagi, H. Xu, H. Sakai, and K. Kobayashi, "Influence of elevated concentrations of atmospheric $\mathrm{CO}_{2}$ on $\mathrm{CH}_{4}$ and $\mathrm{CO}_{2}$ entrapped in rice-paddy soil," Chemical Geology, vol. 218, no. 1-2, pp. 15-24, 2005.

[24] W. Z. De Mello and M. E. Hines, "Application of static and dynamic enclosures for determining dimethyl sulfide and carbonyl sulfide exchange in Sphagnum peatlands: implications for the magnitude and direction of flux," Journal of Geophysical Research, vol. 99, no. 7, pp. 14-607, 1994.

[25] B. H. Byrnes, E. R. Austin, and B. K. Tays, "Methane emissions from flooded rice soils and plants under controlled conditions," Soil Biology and Biochemistry, vol. 27, no. 3, pp. 331-339, 1995.

[26] A. J. Baird, C. W. Beckwith, S. Waldron, and J. M. Waddington, "Ebullition of methane-containing gas bubbles from nearsurface Sphagnum peat," Geophysical Research Letters, vol. 31, no. 21, pp. 2-5, 2004.
[27] T. Tokida, T. Miyazaki, and M. Mizoguchi, "Physical controls on ebullition losses of methane from peatlands," in Carbon Cycling in Northern Peatlands, A. J. Baird, L. R. Belyea, X. Comas et al., Eds., pp. 219-228, AGU, Washington, DC, USA, 2009.

[28] H. Yao and R. Conrad, "Effect of temperature on reduction of iron and production of carbon dioxide and methane in anoxic wetland rice soils," Biology and Fertility of Soils, vol. 32, no. 2, pp. 135-141, 2000.

[29] Y. Liu, K.-Y. Wan, Y. Tao et al., "Carbon dioxide flux from rice paddy soils in central china: effects of intermittent flooding and draining cycles," PLoS ONE, vol. 8, no. 2, Article ID e56562, 2013. 

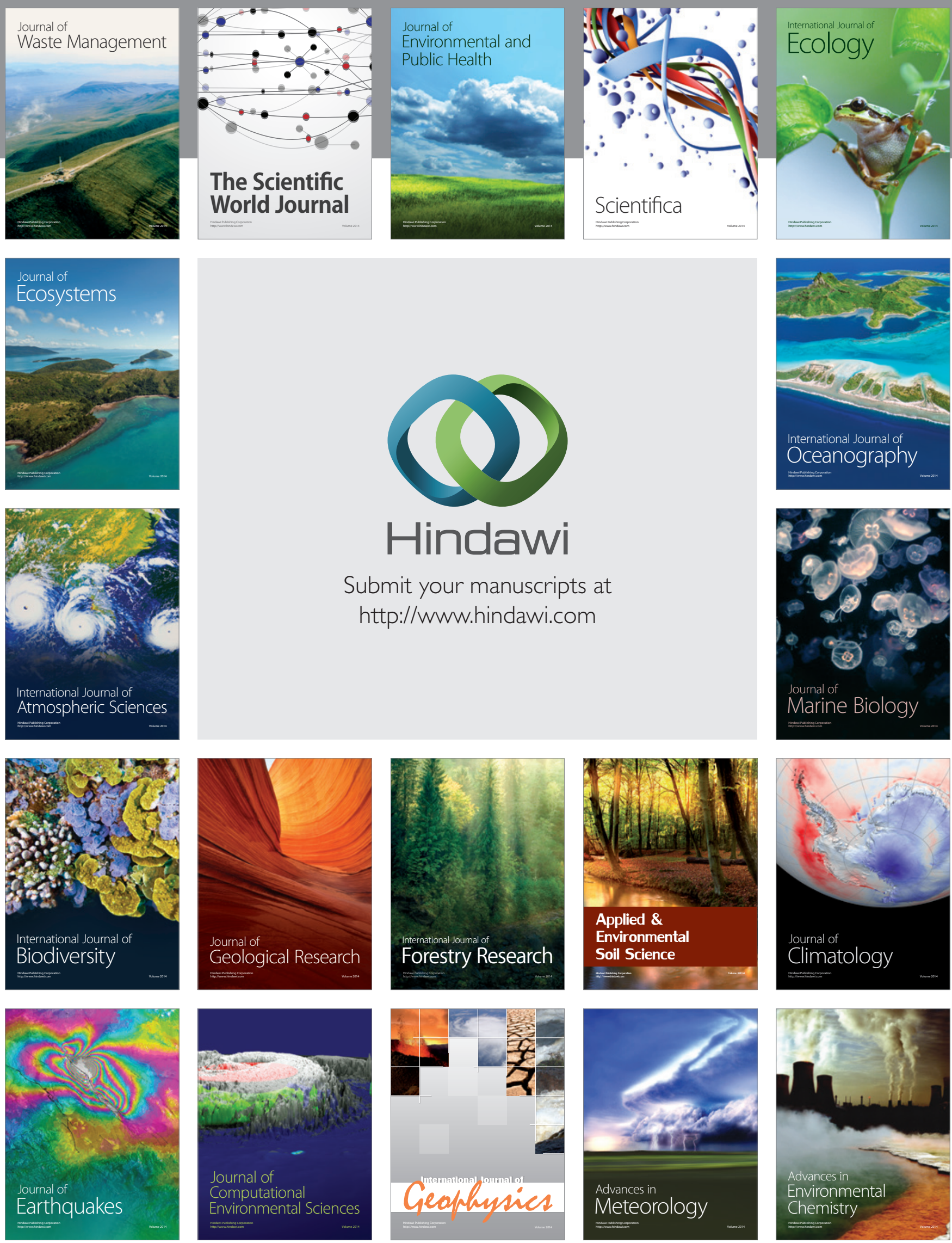